DOI: https://doi.org/10.31933/jimt.v2i4 Received: 22 Februari 2021, Revised: 11 Maret 2021, Publish: 17 Maret 2021

JIMT
JURNAL ILMU MANAJEMEN
TERAPAN

\title{
FAKTOR-FAKTOR YANG MEMPENGARUHI KEPUTUSAN PEMBELIAN, KUALITAS PRODUK, HARGA KOMPETITIF, LOKASI (LITERATURE REVIEW MANAJEMEN PEMASARAN)
}

\author{
Desi Permata Sari ${ }^{1}$ \\ Student of Program Universitas Putra Indonesia YPTK Padang, email: desipermatasari735@gmail.com
}

\section{Corresponding author: Desi Permata Sari ${ }^{1}$}

Abstract: Penelitian ini bertujuan untuk mengetahui Faktor-faktor yang mempengaruhi mempengaruhi Keputusan Penjualan (Y), Kualitas Produk (X1), Harga Kompetitif (X2), Lokasi (X3). Suatu studi literature Manajemen Sumber daya Manusia. Metode penulisan artikel ilmiah ini adalah dengan metode kualitatif dan studi literature atau Library Research. Hasil artikel literature review ini adalah: 1) KualitasProduk (X1) berpengaruh terhadap Keputusan Penjualan (Y), 2) Harga kompetitif (X2) berpengaruh terhadap Keputusan Penjualan (Y), dan 3) Lokasi (X3) berpengaruh terhadap Keputusan Penjualan (Y).

Keyword: Keputusan Penjualan (Y), Kualitas Produk (X1), Harga (X2), Lokasi (X3)

\section{INTRODUCTION}

Pada era globalisasi, perdagangan bebas menjadi suatu fenomena yang harus dihadapi dengan kesiapan yang matang dari berbagi faktor-faktor produksi yang dimiliki perusahaan. Pengaruh perdagangan bebas kini sudah sulit dibendung, semua Negara-negara di dunia akan merasakan dampaknya, untuk itu perusahaan harus disiapkan sebaik mungkin akan tidak tergilas perkembangan arus globalisasi dunia

Keputusan pembelian merupakan seleksi terhadap dua pilihan alternatif atau lebih konsumen pada pembelian (Schiffman dan Kanuk, 2008). Peroses pengambilan keputusan pembelian pada setiap orang pada dasarnya sama, namun peroses pengambilan keputusan pada setiap orang akan diwarnai oleh ciri keperibadian, usia, pendapatan dan gaya hidupnya. Konsumen mempunyai pilihan antara melakukan pembelian dan tidak melakukan pembelian atau pilihan menggunakan waktu, maka konsumen tersebut berada dalam posisi untuk mengambil keputusan. Setiap hari konsumen mengambil berbagai keputusan mengenai setiap aspek kehidupan sehari-hari. Tetapi, kadang mengambil keputusan ini tanpa memikir kan bagaimana mengambil keputusan dan apa yang terlibat dalam proses pengambilan keputusan 
ini. Pilihan alternatif harus tersedia bagi seseorang ketika mengambil keputusan(Schiffman dan Kanuk, 2008)

Konsumen mempunyai pilihan antara melakukan pembelian dan tidak melakukan pembelian atau pilihan menggunakan waktu, maka konsumen tersebut berada dalam posisi untuk mengambil keputusan. Sebaliknya, jika konsumen tidak mempunyai alternatif untuk memilih

dan benar-benar terpaksa melakukan pembelian tertentu atau mengambil tindakan tertentu, maka keadaan satu-satunya tanpa pilihan lain ini bukanlah suatu keputusan (Schiffman dan Kanuk, 2008).

Menurut Tjiptono (2008:25), kualitas produk merupakan perpaduan antara sifat dan karakteristik yang menentukan sejauh mana keluaran dapat memenuhi prasyarat kebutuhan pelanggan atau menilai sampai seberapa jauh sifat dan karakteristik itu memenuhi kebutuhannya, kualitas produk mempunyai delapan faktor yaitu Performance (kinerja), Durability (daya tahan), Conformance to specifications (kesesuaian dengan spesifikasi), Features (fitur), Reliability (reliabilitas), Aesthetics (estetika), Perceived quality (kesan kualitas), dan Serviceability (kemampuan layanan). Kualitas produk yang diberikan perusahaan adalah strategi yang tepat untuk menarik perhatian konsumen. garuh terhadap keputusan pembelian. Kualitas produk adalah suatu tindakan yang diberikan oleh perusahaan untuk memenangkan persaingan di pasar dengan menetapkan sekumpulan perbedaanperbedaan yang berarti pada produk atau jasa yang ditawarkan untuk membedakan produk perusahaan dengan produk pesaingnya, sehingga dapat dipandang atau dipersepsikan konsumen bahwa produk yang berkualitas tersebut mempunyai nilai tambah yang diharapkan oleh konsumen.

Harga adalah sejumlah uang yang dibutuhkan untuk mendapatkan sejumlah barang beserta jasa-jasa tertentu atau kombinasi dari keduanya. Harga merupakan faktor kendali kedua yang dapat ditangani oleh manajemen penjualan atau pemasaran untuk memahami inti pokok tentang pengambilan keputusan yang menyangkut penetapan harga. Harga yang terlalu tinggi akan membentuk persepsi pelanggan bahwa produk kita termasuk pada kategori barang mewah superior (berkualitas tinggi).

Lokasi adalah tempat atau berdirinya perusahaan atau tempat usaha (PeterdanOlson, 2014). Lokasi jasa seringkali tetap merupakan faktor krusial yang berpengaruh terhadap kesuksesan suatu jasa, karena lokasi erat kaitannya dengan pasar potensial penyedia jasa. Secara garis besar, ada dua kemungkinan pertimbangan dalam hal lokasi fasilitas jasa (Tjiptono, 2011) Artikel ini membahas pengaruh Kualitas Produk (X1), Harga (X2), Lokasi (X3) berpengaruh terhadap keputusan pembelian (Y)suatu studi literature Manajemen strategik

\section{Rumusan Masalah.}

Berdasarkan latarbelakanga kan di rumuskan masalah yang akan di bahas pada artikel literature review agar lebih focus pada kajian pustaka dan hasil serta pembahasan nanti, yaitu: 1. Apakah kualitas Produk memiliki hubungan dan berpengaruh terhadap keputusan pembelian 
2. Apakah harga memiliki hubungan dan berpengaruh terhadap keputusan pembelian

3. Apakah lokasi memiliki hubungan dan berpengaruh terhadap keputusan pembelian

\section{KAJIAN TEORI}

\section{Keputusan Pembelian}

Kotler dan Amstrong (2018, hlm 176) keputusan pembelian merupakan sebuah faktor situasional yang tidak terduga. Konsumen dapat membentuk niat beli berdasarkan faktorfaktor seperti pendapatan yang diharapkan, harga yang diharapkan, dan manfaat produk yang diharapkan. Sudaryono (2014, hlm. 208) Keputusan pembelian didefinisikan sebagai suatu pemilihan tindakan dari dua atau lebih pilihan alternatif. Dengan kata lain, orang yang mengambil keptusan harus mempunyai satu pilihan dari beberapa alternatif yang ada. Bila seseorang dihadapkan pada dua pilihan, yaitu membeli dan tidak membeli, dan kemudian dia memilih membeli, maka dia ada dalam posisi membuat suatu keputusan pembelian.

Keputusan pembelian merupakan serangkaian proses yang berawal dari konsumen mengenal masalahnya, mencari informasi tentang produk atau merek tertentu dan mengevaluasi produk atau merek tersebut seberapa baik masing-masing alternative tersebut dapat memecahkan masalahnya, yang kemudian serangkaian proses tersebut mengarah kepada keputusan pembelian (Tjiptono, 2014:21). Selanjutnya Kotler dan Keller (2012:227) menambahkan bahwa, proses keputusan pembelian adalah proses lima tahap yang dilewati konsumen, dimulai dari pengenalan masalah, pencarian informasi, evaluasi alternative yang dapat memecahkan masalahnya, keputusan pembelian, dan perilaku pasca pembelian, yang dimulai jauh sebelum pembelian yang sesungguhnya dilakukan oleh konsumen dan memiliki dampak yang lama setelah itu.

Penjual perlu menyusun struktur keputusan membeli secara keseluruhan untuk membantu konsumen dalam mengambil keputusan tentang pembeliannya. Setiap keputusan membeli mempunyai suatu struktur sebanyak tujuh" (Kotler, 2000:109).

Komponen-komponen tersebut adalah :

a. Keputusan tentang jenis produk.

b. Keputusan tentang bentuk produk.

c. Keputusan tentang merek.

d. Keputusan tentang penjualnya.

e. Keputusan tentang jumlah produk.

f. Keputusan tentang waktu pembelian.

g. Keputusan tentang cara pembayaran.

Indikator Keputusan Pembelian Ada tiga indicator dalam menentukan keputusan pembelian (kotler, 2012), yaitu:

a.Kemantapan pada sebuah produk

b.Kebiasaan dalam membeli produk

c. Kecepatan dalam membeli sebuah produk 
Keputusan pembelian ini sudah banyak di teliti oleh peneliti sebelumnya di antaranya adalah((Ikhsani\& Ali, 2017), (Ali, Narulita, et al., 2018b), (Brata et al., 2017), (Ikhsani \& Ali, 2017), (Ali, 2019), (Yunita \& Ali, 2017), (Mappesona et al., 2020), (Novansa, Hafizh, Ali, 2017), (Sivaram et al., 2020), (Richardo et al., 2020),

\section{Kualitas Produk}

Kotler dan Armstrong (2008:75) mengatakan bahwa kualitas produk merupakan senjata strategis yang potensial untuk mengalahkan pesaing. Selanjutnya Kotler (2009) adalah keseluruhan cirri dari suatu produk yang berpengaruh pada kemampuan untuk memuaskan kebutuhan yang dinyatakan /tersirat. Sedangkan kualitas produk merupakan kemampuan dari produk untuk menjalankan fungsinya yang mencakup daya tahan, kehandalan atau kemajuan, kekuatan, kemudahan dalam pengemasan dan reparasi produk dan ciri-ciri lainnya dalam Luthfia (2012). Menurut Sudaryono (2016:86), kualitas produk didefenisikan sebagai evaluasi menyeluruh pelanggan atas kebaikan kinerja barang atau jasa.

Produk adalah sesuatu yang dapat ditawarkan ke pasar untuk mendapatkan perhatian, untuk dibeli, digunakan atau dikonsumsi yang dapat memenuhi suatu keinginan atau kebutuhan.Produk dapat berupa barang fisik, jasa, pengalaman, acara, orang, tempat, properti, organisasi, informasi dan ide (Kotler dan Keller, 2009)

Menurut David Garvin, untuk menentukan dimensi kualitas produk, dapat melalui delapan dimensi sebagai berikut (Umar, 2002 : Lupiyoadi, 2001) :

1. Performance,

hal ini berkaitan dengan aspek fungsional suatu barang dan merupakan karakteristik utama yang dipertimbangkan pelanggan dalam membeli barang tersebut.

2. Features, yaitu aspek performansi yang berguna untuk menambah fungsi dasar, berkaitan dengan pilihan-pilihan produk dan pengembangannya.

3. Reliability,

hal yang berkaitan dengan probabilitas atau kemungkinan suatu barang berhasil menjalankan fungsinya setiap kali digunakan dalam periode waktu tertentu dan dalam kondisi tertentu pula.

4. Conformance,

hal ini berkaitan dengan tingkat kesesuaian terhadap spesifikasi yang telah ditetapkan sebelumnya berdasarkan keinginan pelanggan.

5. Durability yaitu suatu refleksi umur ekonomis berupa ukuran daya tahan atau masa pakai barang.

6. Serviceability,

yaitu karakteristik yang berkaitan dengan kecepatan, kompetensi, kemudahan, dan akurasi dalam memberikan layanan untuk perbaikan barang

7. Asthetics, 
merupakan karakteristik yang bersifat subyektif mengenai nilai-nilai estetika yang berkaitan dengan pertimbangan pribadi dan refleksi dari preferensi individual.

8. Perceived quality,

konsumen tidak selalu memiliki informasi yang lengkap mengenai atribut-atribut produk. Namun demikian biasanya konsumen memiliki informasi tentang produk secara tidak langsung

Kualitas produk sudah banyak di teliti oleh peneliti sebelumnya di antaranya adalah (Shaharudinet al. (2011), Ackaradejruangsri (2013), Tamunu dan Ferdinand (2014), dan Kalicharan (2014).)(Desfiandi et al., 2017), (M \& Ali, 2017), (Ali, Narulita, et al., 2018a), (M \& Ali, 2017), (Ali, Evi, et al., 2018), (Prihartono \& Ali, 2020), (Riyanto et al., 2017), (Maisah \& Ali, 2020), (Brata et al., 2017), (Thanh Nguyen et al., 2019), (Ali, 2019), and (Anggita \& Ali, 2017b).

\section{Harga}

Kotler dan Keller (2007: 77) mendefinisikan harga adalah satu unsure bauran pemasaran yang menghasilkan pendapatan sedangkan yang lainnya menghasilkan biaya.Selanjutnya Hasan (2008: 298) berpendapat bahwa harga adalah segala bentuk biaya moneter yang dikorbankan oleh konsumen untuk memperoleh, memiliki, memanfaatkan sejumlah kombinasi dari barang beserta pelayanan dari suatu produk.Kemudain Fandy Tjiptono (2007 : 468) harga itu bersifat fleksibel, artinya disesuaikan dengan cepat.

Menurut Suharno dan Sutarso(2010), harga adalah sejumlah uang yang digunakan untuk mendapatkan barang atau jasa. Sumarwan (2011, hlm 369) menyatakan bahwa harga adalah atribut produk atau jasa yang paling sering digunakan oleh sebagian besar konsumen untuk mengevaluasi produk. Maka harha adalah faktor utama yang dipertimbangkan dalam memilih produk maupun jasa. Kotler dan Amstrong (2018, hlm 308) menyatakan bahwa harga merupakan Jumlah uang yang dibebankan untuk sebuah produk atau layanan, atau jumlah dari nilai yang ditukar pelanggan dengan manfaat memiliki atau menggunakan produk atau layanan. Tjiptono (2016, hlm. 219) mendefinisikan bahwa harga merupakan komponen yang berpengaruh langsung terhadap laba perusahaan. Tingkat harga yang ditetapkan mempengaruhi kuantitas yang terjual. Selain itu, secara tidak langsung harga juga mempengaruhi biaya, karena kuantitas yang terjual berpengaruh pada biaya yang ditimbulkan dalam kaitannya dengan efisiensi produksi.

Fandy Tjiptono mengatakan bahwa, harga memiliki dua peranan utama dalam mempengaruhi keputusan beli, yaitu :

1. Peranan alokasi dari harga, yaitu fungsi harga dalam membantu para pembeli untuk memutuskan cara memperoleh manfaat atau utilitas tertinggi yang diharapkan berdasarkan daya belinya. Dengan demikian, adanya harga dapat membantu para pembeli untuk memutuskan cara mengalokasikan daya belinya pada berbagai jenis barang dan jasa. Pembeli membandingkan harga dari beberapa alternatif yang tersedia, kemudian memutuskan alokasi dana yang dikehendaki. 
2. Peranan informasi dari harga, yaitu fungsi harga dalam mendidik konsumen mengenai faktor-faktor produk, seperti kualitas. Hal ini terutama bermanfaat dalam situasi di mana pembeli mengalami kesulitan untuk menilai faktor produk atau manfaatnya secara obyektif.

Ada 4 indikator harga menurut Kotler dan Amstrong (2008 : 278) yaitu:

1) Keterjangkauan harga,

2) Kesesuaian harga dengan kualitas produk,

3) Daya saing harga,

4) Kesesuaian harga dengan manfaat

Harga sudah banyak di teliti oleh peneliti sebelumnya di antaranya adalah (Iswayanti 2010, Labora (2010) Kumar (2012) ) (Christina Catur Widayati et al., 2020), and (C.C. Widayati et al., 2020), (Ali, Narulita, et al., 2018b), (Ikhsani \& Ali, 2017), (Richardo et al., 2020), (Brata et al., 2017), (Anggita \& Ali, 2017a), (Novansa \& Ali, 2017).

\section{Lokasi}

Lupiyoadi dan Hamdani (2009:92) lokasi merupakan berhubungan dengan di mana perusahaan harus bermarkas dan melakukan operasi atau kegiatannya.Kemudian Kotler (2008:51) "Salah satu kunci menuju sukses adalah lokasi, lokasi dimulai dengan memilih komunitas". Keputusan ini sangat bergantung pada potensi pertumbuhan ekonomis dan stabilitas, persaingan, iklim politik,dan sebagainya

Lokasi usaha adalah tempat dimana usaha tersebut akan dilakukan, segala kegiatan mulai dari pengadaan bahan sampai dengan distribusi atau penjualan dan pemasaran kepada konsumen atau pelanggan. Pemilihan lokasi usaha yang tepat akan sangat menunjang perkembangan jalannya usaha.

Faktor-faktor yang secara umum perlu dipertimbangkan dalam pemilihan lokasi perusahaan, adalah: lingkungan masyarakat, kedekatan dengan pasar, ketersediaan tenaga kerja, kedekatan dengan bahan mentah dan supplier, fasilitas dan biaya transportasi, sumber daya alam lain. Selain faktor-faktor tersebut, berbagai faktor lainnya ada beberapa faktor lagi yang perlu dipertimbangkan dalam pemilihan lokasi: harga tanah, dominasi masyarakat, peraturan-peraturan tenaga kerja (labor laws) dan relokasi, kedekatan dengan pabrik-pabrik dan gudang-gudang lain perusahaan maupun para pesaing, tingkat pajak, kebutuhan untuk ekspansi, cuaca atau iklim, keamanan, serta konsekuensi pelaksanaan peraturan tentang lingkungan hidup." (Handoko, 2000)

Keputusan pemilihan lokasi usaha manufaktur dan usaha mikro/ kecil dipengaruhi oleh berbagai macam kriteria pemilihan yang mendasarkan pada kepentingan kompetitif

Menurut Santoso (2011: 183) indicator dari lokasi yaitu:

1) Keterjangkauan lokasi, 
2) Kelancaran akses menuju lokasi,

3) Kedekatan lokasi.

lokasi sudah banyak di teliti oleh peneliti sebelumnya di antaranya adalah Iswayanti 2010, Labora (2010) Kumar (2012))

\section{METODE PENULISAN}

Metode penulisan artikel ilmiah ini adalah dengan metode kualitatif dan studi literature atau Library Research. Mengkaji Buku-buku literature sesuai dengan teori yang di bahas khusunya di lingkup Manajemen Strategi Disamping itu menganalisis artikel-artikel ilmiah yang bereputasi dan juga artikel ilmiah dari jurnal yang belum bereputasi.Semua artikel ilmiah yang di citasi bersumber dari Mendeley dan Scholar Google.

Dalam penelitian kualitatif, kajian pustaka harus digunakan secara konsisten dengan asumsi-asumsi metodologis. Artinya harus digunakan secara induktif sehingga tidak mengarahkan pertanyaan-pertanyaan yang diajukan oleh peneliti. Salah satu alasan utama untuk melakukan penelitian kualitatif yaitu bahwa penelitian tersebut bersifat eksploratif, (Ali \& Limakrisna, 2013).

Selanjutnya dibahas secara mendalam pada bagian yang berjudul" Pustaka Terkait" (Related Literature) atau Kajian pustaka( "Review of Literature"), sebagai dasar perumusan hipotesis dan selanjutnya akan menjadi dasar untuk melakukan perbandingan dengan hasil atau temuan-temuan yang terungkap dalam penelitian, (Ali \& Limakrisna, 2013).

\section{Conceptual Framework}

Berdasarkan rumusan masalah penulisan artikel ini dan kajian studi literature review baik dari buku dan artikel yang relevan, maka di perolah kerangka artikel ini seperti di bawah ini.

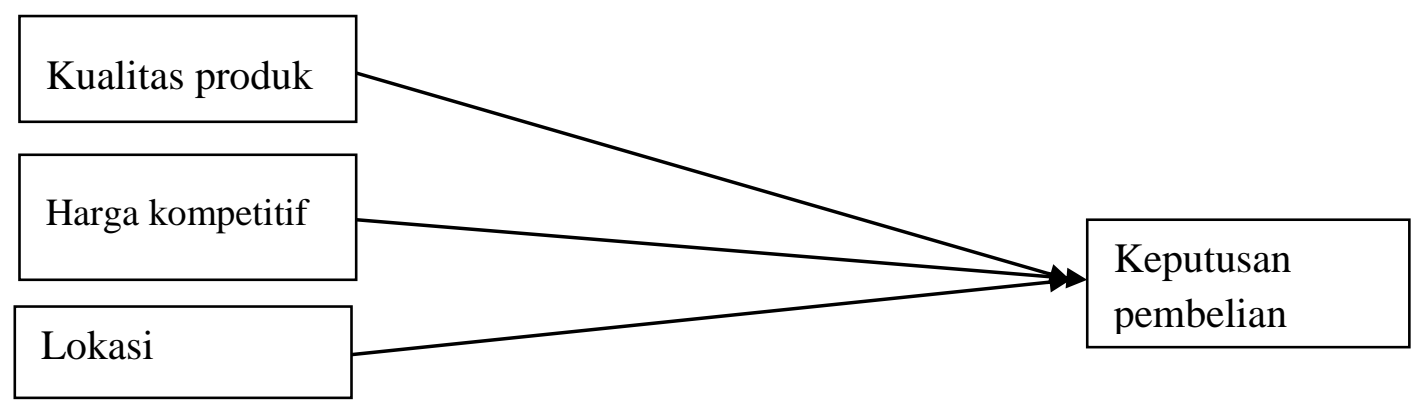

\section{Gambar 1: Conceptual Framework}

Berdasarkan Kajian teori dan review hasil dari artikel yang relevan serta gambar dari conceptual framework, kualitas produk, harga kompetitif, dan lokasi berpengaruh terhadap keputusan pembelian 
Selain dari tiga variabel exogen ini yang mempengaruhi keputusan pembelian, masih banyak variabel lain yang mempengaruhinya diantaranya adalah:

1. Pelayanan

2. lingkungan

3. Kelengkapan produk

4. promosi

\section{KESIMPULAN DAN SARAN \\ Kesimpulan}

Berdasarkan rumusan artikel dan pembahasan maka dapat di dirumuskan hipotesis untuk riset selanjutnya:

1. Kualitas produk berpengaruh positif signifikan terhadap keputusan pembelian

2. Harga berpengaruh positif signifikan terhadap keputusan pembelian

3. Lokasi berpengaruh signifikan terhadap keputusan pembelian

\section{Saran}

1. Bersdasarkan Kesimpulan di atas, maka saran pada artikel ini adalah bahwa masih banyak factor lain yang mempengaruhi keputusan pembelian selain dari kualitas produk, harga, dan lokasi pada semua tipe dan level organisasi atau perusahaan,oleh Karena itu masih di perlukan kajian yang lebih lanjut untuk mencari faktor-faktor lain apa saja yang dapat memepengaruhi keputusan pembelian selain yang varibel yang di teliti pada arikel ini.Faktor lain tersebut seperti kualitas layanan, lingkungan Kelengkapan produk

dan promosi

\section{DAFTAR PUSTAKA}

Ali, H. (2019). Purchase Decision And Repurchase Models: Product Quality And Process Analysis (Case Study Of House Ownership Credit Financing In Permata Sharia Bank Jakarta). Scholars Bulletin. Https://Doi.Org/10.36348/Sb.2019.V05i09.006

Ali, H., Evi, N., \& Nurmahdi, A. (2018). The Influence Of Service Quality , Brand Image And Promotion On Purchase Decision At Mcu Eka Hospital. Business And Management Studies. Https://Doi.Org/10.21276/Sjbms.2018.3.1.12

Ali, H., Narulita, E., \& Nurmahdi, A. (2018a). Saudi Journal Of Business And Management Studies ( Sjbms ) The Influence Of Service Quality, Brand Image And Promotion On Purchase Decision At Mcu Eka Hospital. Business And Management Studies. Https://Doi.Org/10.21276/Sjbms.2018.3.1.12

Ali, H., Narulita, E., \& Nurmahdi, A. (2018b). The Influence Of Service Quality, Brand Image And Promotion On Purchase Decision At Mcu Eka Hospital. Saudi Journal Of Business And Management Studies. Https://Doi.Org/10.21276/Sjbms.2018.3.1.12

Anggita, R., \& Ali, H. (2017a). The Influence Of Product Quality, Service Quality And Price To Purchase Decision Of Sgm Bunda Milk. Scholars Bulletin. Https://Doi.Org/10.21276/Sb

Anggita, R., \& Ali, H. (2017b). The Influence Of Product Quality, Service Quality And Price To Purchase Decision Of Sgm Bunda Milk (Study On Pt. Sarihusada Generasi Mahardika Region 
Jakarta, South Tangerang District). Scholars Bulletin. Https://Doi.Org/10.21276/Sb

Brata, B. H., Husani, S., \& Ali, H. (2017). The Importance Of Quality Products, Price, Promotion, And Location To Product Purcese Decision On Nitchi At Pt. Jaya Swarasa Agung In Central Jakarta. Saudi Journal Of Business And Management Studies. Https://Doi.Org/10.21276/Sjbms

Desfiandi, A., Fionita, I., \& Ali, H. (2017). Implementation Of The Information Systems And The Creative Economy For The Competitive Advantages On Tourism In The Province Of Lampung. International Journal Of Economic Research.

Handoko, T. H. (2000). Dasar-Dasar Manajemen Produksi Dan Operasi. Bpfe.

Ikhsani, K., \& Ali, D. H. (2017). Keputusan Pembelian: Analisis Kualitas Produk, Harga Dan Brand Awareness (Studi Kasus Produk Teh Botol Sosro Di Giant Mall Permata Tangerang). In Jurnal Swot.

M, A., \& Ali, H. (2017). Model Kepuasan Pelanggan: Analisis Kualitas Produk Dan Kualitas Layanan Terhadap Citra Merek Pada Giant Citra Raya Jakarta. Jurnal Manajemen. Https://Doi.Org/10.24912/Jm.V21i3.254

Maisah, \& Ali, H. (2020). Entrepreneurship Culture Development Process: Implementation Of Islamic Education Values In The Batik Jambi (Case Study In Seberang Jambi Community). Talent Development And Excellence.

Mappesona, H., Ikhsani, K., \& Ali, H. (2020). Customer Purchase Decision Model, Supply Chain Management And Customer Satisfaction: Product Quality And Promotion Analysis. International Journal Of Supply Chain Management.

Novansa, Hafizh, Ali, H. (2017). Purchase Decision Model: Analysis Of Brand Image, Brand Awareness And Price (Case Study Smeco Indonesia Sme Products). Saudi Journal of Humanities And Social Sciences.

Novansa, H., \& Ali, H. (2017). Purchase Decision Model: Analysis Of Brand Image, Brand Awareness And Price (Case Study Smeco Indonesia Sme Products). Saudi Journal of Humanities And Social Sciences. Https://Doi.Org/10.21276/Sjhss

Prihartono, \& Ali, H. (2020). The Promises Ethics And Marketing Concept Strategy As A Competitive Advantage On Private Higher Education (A Survey On Perception Of Product Attributes And Promotion Mix In Indonesia). Talent Development And Excellence.

Richardo, Hussin, M., Bin Norman, M. H., \& Ali, H. (2020). A Student Loyalty Model: Promotion, Products, And Registration Decision Analysis-Case Study Of Griya English Fun Learning At The Tutoring Institute In Wonosobo Central Java. International Journal Of Innovation, Creativity And Change.

Riyanto, S., Adila, L., \& Ali, H. (2017). The Effect Of Incentives And Job Enthusiasm To Productivity Of Go-Jek Driver At Pt . Go-Jek Indonesia. Journal Of Research In Business And Management.

Sivaram, M., Munawar, N. A., \& Ali, H. (2020). Determination Of Purchase Intent Determination Of Purchase Intention Through Brand Awareness And Perceived Quality (Case Study: For Consumers Pt. Sentosa Santosa Finance Tangerang Area). Dinasti International Journal of Management Science. Https://Doi.Org/10.31933/Dijms.V1i2.71

Thanh Nguyen, P., Ali, H., \& Agung Hudaya. (2019). Model Buying Decision And Repeat Purchase:

Product Quality Analysis (Case Study Of Bank Permata Syariah Jakarta Kpr Financing Customers). Dinasti International Journal Of Management Science. Https://Doi.Org/10.31933/Dijms.V1i1.29

Widayati, C.C., Ali, H., Permana, D., \& Nugroho, A. (2020). The Role Of Destination Image On 
Visiting Decisions Through Word Of Mouth In Urban Tourism In Yogyakarta. International Journal Of Innovation, Creativity And Change, 12(3).

Widayati, Christina Catur, Ali, H., Permana, D., \& Nugroho, A. (2020). The Role Of Destination Image On Visiting Decisions Through Word Of Mouth In Urban Tourism In Yogyakarta. International Journal Of Innovation, Creativity And Change.

Yunita, D., \& Ali, H. (2017). Model Of Purchasing Decision ( Renting ) Of Generator Set: Analysis Of Product Quality, Price An Service At Pt . Hartekprima Listrindo. Economics, Business And Management. Https://Doi.Org/10.21276/Sjebm.2017.4.11.12 